UNIO - EU Law Journal. Vol. 7, No. 1, July 2021, pp 120-137.

®2021 Centre of Studies in European Union Law

School of Law - University of Minho

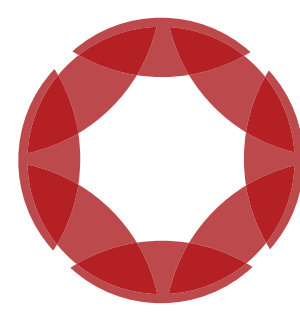

\title{
A consensus solution for the taxation of the digital economy
}

\section{Marina Barata*}

ABSTRACT: The taxation of the digital economy is not a new subject but its fast development demands a solid solution for this new way of doing business and generating profit and growth. The solution for this problem should be achieved at a global level, which has turned out to be a complex task. Therefore, the work we aim to do here is to identify and expose the path that has been followed by the international community (in general), and by the European Union, in particular, for the taxation of profits of companies with a significant digital presence and to what extent the lack of an unambiguous solution, within the Union, may condition its own objectives. But achieving a consensual solution comes with a bigger problem: is the unanimity rule established for tax policies, where decisions are taken by a special legislative procedure, suited for the European Union's goal for a strong and dynamic single market, capable of competing with the world's leading economies?

KEYWORDS: Digital Economy - taxation - unanimity rule - EU tax policies.

\footnotetext{
* Master in Law by the University of Coimbra.
} 


\section{Introduction}

The COVID-19 pandemic has accelerated a trend we have been witnessing for some years now, the disruption of the pillars on which the economy as we know it is based. In times of quarantine and teleworking, digital tools and e-commerce have become strong allies in citizens' lives, helping mitigate the effects of confinement. What used to be done physically and in person is now done online. And if e-commerce is the future, taxation of this new way of creating value becomes an even more relevant issue. $^{1}$

The development of the digital economy has become a growing challenge for national tax systems, which were designed at a time when most companies still had a relevant physical presence. Incidentally, it is physical presence (whether through domicile or a permanent establishment) that gives governments the justification to exercise their tax powers. As the European Council stated already in October 2017, " an effective and fair taxation system fit for the digital era".

In fact, it is undeniable this dematerialisation of business and the ever-increasing importance of digital activities within the economy and in the daily lives of consumers and economic agents in general. Whether for personal or professional reasons, individuals and companies rely, increasingly and on a constant basis, on digital tools.

Digitalisation is putting pressure on the European tax system and if a minimum of tax harmonisation is not achieved, the European Union's goal of economic integration and the completion of the Single Market will not be realised.

In addition, we must not forget that tax collection is an important, if not the most significant, source of revenue collection for States.

On 27 May 2020, the European Commission published a COVID-19 recovery plan that aims to strengthen the economies of Member States weakened by the effects of the pandemic. In this context, the creation of new taxes on the digital economy or the restructuring of national tax systems to tax activities that are not provided for in current legislation is one of the Commission's concerns. ${ }^{3}$

The work we aim to do here is to identify and expose the path that has been followed by the international community (in general), and by the European Union, in particular, for the taxation of profits of companies with a significant digital presence and to what extent the lack of an unambiguous solution, within the Union, may condition its own objectives.

Not without saying that on 12 of July of 2021, after years of international debate, Finance Ministers and G20 Central Banks Governors, achieved an historical global agreement that may ensure a fairer taxation of multinational companies. ${ }^{4}$

The technical details of the agreement will be negotiated in the upcoming months in order to reach a final agreement in October 2021, and as soon as this final (and consensual) agreement is signed by all 139 Members of the OECD, the Commission

\footnotetext{
${ }^{1}$ The need to find an effective response to taxing this new way of generating value among digital businesses is almost like identifying the Gray Rhino that Michele Wucker talks about in her book The gray rbino: how to recognize and act on the obvious dangers we ignore (New York: St Martin's Press, 2016).

${ }^{2}$ European Council, “Leaders' Agenda”, accessed August 20, 2021, https://www.consilium.europa. eu/media/33333/en_leaders-agenda_note-on-taxation.pdf.

${ }^{3}$ Johan Barros, "Full steam ahead for a taxing autumn", Tax Journal, article 116, accessed August 20, 2021, https:/ / www.taxjournal.com/articles/eu-watch-16-july.

${ }^{4}$ European Commission, "Taxation: historic global agreement to ensure fairer taxation of multinational enterprises”, accessed August 20, 2021, https://ec.europa.eu/commission/presscorner/detail/en/ ip_21_3582.
} 
will move swiftly to propose measures for their implementation in the EU, in line with the EU's tax agenda and the needs of the Single Market. ${ }^{5}$

Although we now see the possibility of a consensus-based global agreement, I think it is still relevant to look at how things evolved over the years.

\section{Why is the world in need for a change?}

Companies now have the possibility to choose the ideal location to conduct their businesses, the barrier of proximity to the customer and supplier is greatly facilitated with the digital economy, and the tax system is a key factor in this choice. The evolution of business models and the growth of the digital economy have resulted in non-resident companies operating in a market jurisdiction quite different from the one for which the international tax rules were designed.

Indeed, companies may locate assets, functions or risks in low-tax jurisdictions or countries with preferential regimes, and thus allocate income in those locations. In the context of the digital economy, rights to intangibles are often transferred to companies domiciled in jurisdictions where the income from those intangibles is subject to reduced tax rates or not at all due to the application of a preferential regime.

The fact that a physical presence is less and less necessary in today's typical business structures creates challenges for international taxation, the solution to which cannot be achieved unilaterally, since it requires joint and coordinated action by all States. Tax policy can no longer be managed within national borders alone. Aggressive tax planning and tax-base erosion cannot be stopped unilaterally.

The application of current corporate tax rules to the digital economy has led to a mismatch between where profits are taxed and where value is created. The rules in force no longer fit the current context, where cross-border trade without physical presence has been facilitated, where companies rely heavily on intangible assets that are difficult to value, and where user-generated content and data collection become key activities for value creation for digital businesses.

Thus, the top 10 of the largest companies in the world today are technology companies such as Facebook, Amazon, Alphabet ${ }^{6}$, surpassing historical giants such as Ford, BMW, Boeing, Siemens, or General Electric.

The arrival of these digital giants gave rise to new taxation issues.

For instance, how can Germany (or another Member State) tax profits generated by Facebook in Germany since Facebook has no domicile or permanent establishment in Germany? Or how can tax companies that use Facebook as a sales channel be taxed?

Amazon, a US multinational technology company based in Seattle, Washington, mostly engaged in e-commerce, cloud computing, streaming and artificial intelligence, considered one of the big five technology companies, has much of its sales in the Netherlands, mostly in non-digital products. However, it has no subsidiary company operating in the Netherlands, and no permanent establishment ${ }^{7}$ for taxation purposes. There is no nexus or physical connecting element that gives the Dutch Government the right to tax Amazon's income generated in its territory.

\footnotetext{
${ }^{5}$ Answering the question on how will this be implemented in the European Union?, see European Commission, "Global Agreement on Corporate Taxation: frequently asked questions", accessed August 20, 2021, https://ec.europa.eu/commission/presscorner/detail/pt/qanda_21_3564.

6 "Most Valuable Companies in the World - 2021", accessed August 20, 2021, https:/ fxssi.com/top10-most-valuable-companies-in-the-world.

${ }^{7}$ For the application of article 5 of the Model Tax Convention on Income and Capital.
} 
After all, the current corporate tax rules are based on the principle that profits should be taxed where the value is created. However, these rules were originally conceived at the beginning of the 20th century for traditional "physical" companies. Under the current legal framework, the right to tax is inextricably linked to physical presence. This means that a company's income is taxed where it is domiciled or carries on business. Non-residents for tax purposes only become liable to tax in a country if they have a physical presence there, in the form of a permanent establishment. However, such rules are insufficient to encompass the reality of digital activities, for which physical presence is no longer a necessity. In these new business models, the way of generating value is genetically different from traditional trade. Thus, a paradigm shift in the tax system is needed to avoid a distortion of competition with a negative impact on public revenue. ${ }^{8}$

Another example that I find interesting is the example of Netflix in Italy. In October 2019 Italy decided to sue Netflix for tax evasion. "The Milan tribunal has opened the probe as the prosecutors believe Netflix has sufficient physical presence in Italy - including fiber optic cables and servers - to be recognized and qualified as a local business that should be paying taxes".

We will not get lost in the success of this action or exploring the concept of permanent establishment present in Article 5 of the Model Tax Convention on Income and Capital, but this brief example serves to reinforce the idea that, with the development of the digital economy, it is becoming increasingly difficult to accurately determine, according to the international rules in force, which country can (or should) tax the income of a multinational company with digital activity.

And another question arises. Is it necessary to revisit the concept of income/ value? When we talk about digital economy, we must quantify, define in substance, what is the value generated. ${ }^{10}$

In this panorama, jurisdictions that see their tax revenues affected are calling for a more equitable distribution of taxes from digital economy and there is consensus in arguing that the solution to the taxation of the digital economy should be achieved at a global level.

The issue has been raised and analysed in international fora, and some solutions for the taxation of this new form of economy have already been put forward. Although none of them is adequate or free of problems, we will list some solutions/options for taxation of the digital economy that have been discussed at international level:

Digital Permanent Establishment: ${ }^{11}$ In the final report on Action 7 of the BEPS, the OECD considered changes to Article 5 of the Model Tax Convention on Income and Capital to include the concept of digital establishment, using the concept of significant economic presence. This solution immediately presents

\footnotetext{
${ }^{8}$ In the Opinion of the European Economic and Social Committee on "Taxation in the digitalised economy", of 17 July 2019, the expert group concluded that "there should not be a special tax regime for digital companies. The general rules should rather be applied or adapted so that 'digital' companies are treated in the same way as others".

9 "Bloomberg news", accessed August 20, 2021, https:/ / www.bloomberg.com/news/articles/2019-10-03/ italy-said-to-investigate-netflix-for-failing-to-file-tax-return.

${ }^{10}$ Is important to define the concept so it can be applied, for example, to companies such as Alphabet, a holding company that manages companies like Google or YouTube and creates income from intangible assets whose value has been generated in several countries.

${ }^{11}$ For further developments, and since our focus is on the solutions advanced by the EU, see OECD/ G20 Base Erosion and Profit Shifting Project, "Preventing the Artificial Avoidance of Permanent Establishment Status, Action 7 - 2015 Final Report”, accessed August 20, 2021, https://read.oecdilibrary.org/taxation/preventing-the-artificial-avoidance-of-permanent-establishment-status-action7-2015-final-report_9789264241220-en, 16.
} 
difficulties in the concept of significant digital presence and may create more situations of inequality.

Withholding tax on certain digital transactions: ${ }^{12}$ Another initiative considered and discussed at the international level was the introduction of a definitive withholding tax on the gross revenue generated in the e-commerce operations of non-resident companies. This solution raises questions as to its applicability in the relationship with individuals and legal issues of discrimination/neutrality. ${ }^{13}$

Equalisation Levy: ${ }^{14}$ This is a levy rate applicable on digital transactions with non-resident entities that have a significant economic presence in the jurisdiction of consumption/use, in order to offset the loss of tax revenue and thus place residents and non-residents on an equal tax burden. This tax creates some perplexity to the extent that, being levied on income rather than profit, it comes close to VAT. Therefore, it is a difficult tax to classify and the classification of the tax is fundamental, if only to avoid double taxation.

In addition, other problems may arise. Not all digital companies are as successful as Google or Amazon. Companies like, for example, Spotify hardly generate any profit, "but, since they are operating around the European Union and most people use that platform, based on this new 'revenue taxation approach', Spotify will have to pay taxes in all countries possible from 2020 on". ${ }^{15}$ By introducing this new tax, digital start-ups will not be able to grow quickly, which could lead to a loss of competitiveness of the European Union compared to the United States or China. ${ }^{16}$

These and other solutions were identified and addressed by the OECD in the BEPS Action 1 Report - Addressing the Tax Challenges of the Digital Economy of October 2015, which left the commitment to continue working on this issue at international level. ${ }^{17}$

The European Union has also had the opportunity to comment on unilateral measures envisaged by Member States, stating that measures applied individually are very different in terms of scope and justification, and may represent a greater risk of fragmentation of the Single Market and distortion of competition, constituting an obstacle to the development of new digital solutions and to the competitiveness of the Union as a whole. ${ }^{18}$

${ }^{12}$ OECD/G20 Base Erosion and Profit Shifting Project, "Preventing the Artificial Avoidance of Permanent Establishment Status, Action 7 - 2015 Final Report”, 115.

${ }^{13}$ OECD/G20 Base Erosion and Profit Shifting Project, "Preventing the Artificial Avoidance of Permanent Establishment Status, Action 7 - 2015 Final Report”, 115 to 117.

${ }^{14}$ OECD/G20 Base Erosion and Profit Shifting Project, "Preventing the Artificial Avoidance of Permanent Establishment Status, Action 7 - 2015 Final Report”, 117.

${ }^{15}$ Professor Dr. Hans van den Hurk, "Tax and Digital Economy - Will Pillar One be the Solution?”, The EC Tax Journal, v. 18, Feb 2020, 134.

${ }^{16}$ European Commission, "Competition Policy for the digital era - Final report", accessed August 20, 2021, https:/ / ec.europa.eu/competition/publications/reports/kd0419345enn.pdf.

${ }^{17}$ OECD/G20 Base Erosion and Profit Shifting Project, "Addressing the Tax Challenges of the Digital Economy, Action 1 - 2015 Final Report”, 151.

${ }^{18}$ European Commission, Communication from the Commission to the European Parliament, the European Council and the Council, "Towards a more efficient and democratic decision making in EU tax policy”, Strasbourg, 15.1.2019, COM(2019) 8 final, “COM (2019) 8 final”, reads "Increasingly, the only way that Member States can achieve their policy goals and fend off threats to their tax bases is by working together", accessed August 20, 2021, https://eur-lex.europa.eu/legal-content/en/TXT/ HTML/?uri=CELEX:52019DC0008\&from=sl; or in the Opinion of the European Economic and Social Committee on "Taxation in the digitalised economy", where the expert group concludes that 
The aforementioned BEPS Action 1 Report emerged in a specific context of fighting tax fraud and evasion in the digital economy at the request of the G20. In this first report of October 2015, the OECD analyses the different and possible options to address the challenges arising from the digital economy, identifying the tax strategies used by large multinationals to tax-base erosion.

The first action in the BEPS report, cross-cutting, is on the digital economy. The concept of permanent establishment was reviewed so that companies do not, on one hand, benefit from this condition inappropriately and, on the other hand, avoid this condition whenever it is more favourable to them. Among other issues, it analysed the importance of intangible assets, the use of databases, the dissemination of value chains where the different stages of production are spread across several countries and the fight against tax planning by multinational companies.

In March 2018, continuing the work started in 2015, the OECD publishes an Interim Report - Tax Challenges arising from Digitalisation -, also dedicated to the challenges of digital economy. In this 2018 Interim Report, the OECD not only analyses some interim measures implemented by some States, but also focuses on global and long-term solutions, with particular focus on the review of nexus rules and profit allocation rules, aiming to align the distribution of taxing rights among the different jurisdictions, according to the location of digital economic activities and their value creation. Therefore, we have witnessed the first steps taken towards changing the basic tax criteria structured on the physical presence of companies.

However, progress at the international level remained difficult due to the complex nature of the problem, the wide range of issues that need to be resolved and the fact that the different political and economic interests of several states are not always easily reconcilable.

At the OECD level were divergent positions on how the issue should be approached. In the 2018 interim report that "there are divergent views on how the issue should be approached", and "there is no consensus on the need for, or merits of, interim measures, with a number of countries opposed to such measures". ${ }^{19}$

In any case, the report expressed the intention to continue the dialogue and work regarding the digital economy tax challenges, in order to achieve a single and consensual position in 2020, after an amendment in 2019.

On 28 and 29 May 2019, the OECD approved a report - Programme of Work. to Develop a Consensus Solution to the Tax Challenges Arising from the Digitalisation of the Economy, Inclusive Framework on BEPS — which contains the path travelled since then to find a consensual solution on this matter, recognising, however, that the solution still requires more in-depth economic impact studies to reach a long-term solution. More than this, the aforementioned report proves that the international community is focused on studying the problem and is committed to meet the (perhaps audacious) target of reaching a consensual position by $2020 .^{20}$

\footnotetext{
"any changes to the rules for allocating taxation rights of profits among countries must be coordinated globally, in order to better harness the benefits of globalisation, with proper global governance and global rules", accessed August 20, 2021, https://eur-lex.europa.eu/legal-content/EN/TXT/PDF/? uri=CELEX:52018IE2781\&from $=E N$, point 1.4.

${ }^{19}$ OECD/G20 Base Erosion and Profit Shifting Project, "Tax Challenges Arising from Digitalisation - Interim Report 2018. Inclusive Framework on BEPS”, accessed August 20, 2021, https://www. oecd-ilibrary.org/docserver/9789264293083-en.pdf?expires $=1625572235 \& \mathrm{id}=\mathrm{id} \&$ accname $=$ guest \&checksum $=096488$ D3BED0CD67CF78CA83CD122078.

${ }^{20}$ For some authors this Report already represents a relevant paradigm shift. See, for example, Hans
} 
On 12 July of 2021 members of the Organization for Economic Co-operation and Development (OECD) / G20 reached a consensus solution. The discussion focused on two broad work streams: (i) Pillar One - the partial re-allocation of taxing rights; and (ii) Pillar Two - the minimum effective taxation of profits of Multinational Enterprises. ${ }^{21}$

\section{The Digital Tax Package P2 $^{22}$}

The European Commission has decided to go a step further by proposing a harmonised approach to solve the problem, and following a Communication presented in September $2017,{ }^{23}$ has come forward with a legislative package concerning digital economy taxation.

In this communication, the Commission has recognised that the Digital Single Market is one of the 10 political priorities of the European Union, as it generates wealth for the Union, creates jobs and transforms public services. But it also recognises that the transformation of business models, with intangible assets playing an increasingly important role, puts enormous pressure on the European tax system.

The Commission recognises that "the EU Digital Single Market needs a modern and stable tax framework. for the digital economy to stimulate innovation, tackle market fragmentation and allow all players to tap into the new market dynamics under fair and balanced conditions. It is essential to ensure tax certainty for business investment and to prevent new tax loopholes emerging in the Single Market". ${ }^{24}$

It is also recognized that the effort must be coordinated and achieved at international level, but that attempts have proved insufficient. As such, the Commission concludes in the communication to Parliament and Council that "the time to act has now come. The Commission wants an ambitious EU agenda on the matter and a common EU approach to ensure that the digital economy is taxed effectively and in a way that ensures fairness and supports growth". ${ }^{25}$

\footnotetext{
Van den Hurk, "Tax and digital economy - Will pillar one be the solution?", when he writes the following: "2019 was the year in which the OECD proposed a real change in the international tax rules. The consultation report The Tax Challenges of Digitalisation of the Economy was published. It included some radical reforms which dealt with the main point of discussion in international taxation since 1923, namely the arm's length principle".

${ }^{21}$ Pillar One aims to adapt the international rules on how the taxation of corporate profits of the largest and most profitable MNE is shared amongst countries, to reflect the changing nature of business models, including the ability of companies to do business without a physical presence.

Pillar Two will set a floor to excessive tax competition. It aims to ensure that multinational businesses are subject to a minimum effective level of tax on all of their profits each year. European Commission, "Global Agreement on Corporate Taxation: frequently asked questions", accessed August 20, 2021, https://ec.europa.eu/commission/presscorner/detail/pt/qanda_21_3564.

${ }^{22}$ Before further developments on this particular subject, it is important to say that following the Global Agreement on Corporate Taxation achieved by the members of the G20, in July 2021, the Commission announced that the works for implementation of a digital tax are suspended. Nevertheless, it is useful to dissect these two proposals and see the work developed by the Commission.

${ }^{23}$ European Commission, Communication from the Commission to the European Parliament and the Council, "A fair and efficient Tax System in the European Union for the Digital Single Market", Brussels, 21.9.2017, COM(2017) 547 final, accessed August 20, 2021, https://eur-lex.europa.eu/ LexUriServ/LexUriServ.do?uri=COM:2017:0547:FIN:EN:PDF.

${ }^{24} \operatorname{COM}(2017) 547$ final.

${ }^{25} \operatorname{COM}(2017) 547$ final, 3.
} 
Accordingly, on 21 March 2018, the Commission launched two proposals for Directives, the Digital Tax Package, ${ }^{26}$ which aims to add value to the international debate on the subject and respond to the desire to achieve a fair and equitable tax system in the European Union.

The Digital Tax Package encompasses the Proposal for a Council Directive 2018/0072, which lays down rules relating to the corporate taxation of a significant digital presence, and the Proposal for a Council Directive 2018/0073 on the common system of a digital services tax on revenues resulting from the provision of certain digital services, on which we will elaborate further.

The proposals presented are guided by a common criterion: the user value creation, where the number of users, insofar as they play a predominant role in value creation, is one of the main requirements in digital activities taxation.

The proposals aim to implement two different solutions: (i) a long-term solution consisting in extending the concept of permanent establishment to situations of significant digital presence (SDP), as set out in Proposal of a Directive 2018/0072, and (ii) another short-term solution aimed at creating a tax on certain revenues from digital activities, the Digital Service Tax (DST), introduced by Proposal for a Directive 2018/0073.

However, due to their still embryonic nature, these forms of taxation raise a variety of issues that require constant debate, namely, and merely as an example, whether these measures will not result, even if indirectly, in an unacceptable restriction on international trade, namely in light of the rules of the World Trade Organisation. It is therefore necessary to discuss it, both at national and international level, in favour of a coordinated and sound taxation system for digital activities.

\subsection{Proposal for a Directive 2018/0072 - Digital Permanent Establishment}

The Proposal for Council Directive 2018/0072 (CNS), presented on 21 March 2018, aims to address the problems raised by the digital economy through a comprehensive solution within the existing Member States' corporate tax systems. It sets out a common system for taxing digital activities in the European Union which properly considers the features of the digital economy. One of the main objectives of this proposal is to improve the resilience of the Internal Market as a whole to meet the challenges of the digital economy. As digital businesses can engage in crossborder activities without any physical presence in a jurisdiction, rules ensuring that such businesses pay taxes in the places where value is generated are indispensable. It is recognised that a common initiative to ensure harmonised application of tax rules on significant digital presence is necessary, as unilateral and divergent approaches by individual Member States could prove ineffective and fragment the Single Market, creating conflicts between national policies, as well as tax distortions and obstacles for businesses operating in the European Union.

Before turning to the more detailed analysis of this proposal for a directive, it should be noted that the proposal for a Common Consolidated Corporate Tax Base (CCCTB) could be a solution to ensure fairer and more efficient taxation of companies in the European Union. However, it could not provide a structural solution to some of the important challenges in digital company taxation. This is because the scope of the CCCTB is limited (only mandatory for multinational companies)

\footnotetext{
${ }^{26}$ European Commission, "Fair taxation of the Digital Economy", accessed August 20, 2021, https:// ec.europa.eu/taxation_customs/business/company-tax/fair-taxation-digital-economy_en.
} 
and the definition of permanent establishment is still based on the idea of physical presence. Regarding the profit attribution formula for large multinational groups, the approach to the Common Consolidated Corporate Tax Base apportionment formula should be adapted to also reflect digital activities. ${ }^{27}$ However, while this solution would not be sufficient to ensure fair taxation of digital activities of companies, the Commission has already identified the problem and is ready to work together with Member States and the European Parliament to examine how the provisions of this proposal of a directive can be incorporated into the CCCTB. ${ }^{28}$

The Commission therefore recommends that the rules of this Proposal should be incorporated into Member States' tax systems and into the Commission's proposal for a CCCTB and should also be reflected in corresponding changes to the OECD Tax Convention at international level.

The proposal would broadly introduce the concept of Digital Permanent Establishment into Member States' tax systems so that they could levy corporate income tax on the profits of non-resident entities attributable to a significant digital presence in their territory, due to a functional and independently conducted analysis of physical presence.

Article 2 of the Proposal defines the subjective scope of application, covering all enterprises subject to corporate income tax, both enterprises established in the European Union and enterprises established outside the European Union with which there is no double taxation treaty with the Member State where a significant digital presence is identified.

If there is a double taxation treaty between the Member State and the nonresident State for taxation purposes, the proposal of a directive will only apply if that treaty includes similar provisions on significant digital presence creating similar rights and obligations in relation to that jurisdiction outside the European Union (Article 2, second paragraph). Thus, only enterprises incorporated or established in a jurisdiction outside the European Union with which a double taxation treaty has been concluded will not be covered, to avoid any violations of such Treaties.

Without dwelling on the merits of this norm, we may say that the expression "similar provisions" can generate margin for different interpretations as to its meaning and scope of application. Although it is intuitive that the concept of "similarity" in

\footnotetext{
${ }^{27}$ See Proposal for Council Directive 2018/0072, 4.

${ }^{28}$ It can be read in the Report of 22 February 2018 on the proposal for a Council directive on a Common Consolidated Corporate Tax Base (CCCTB) "As pointed out in the proposal of 16 March 2011 for a Council Directive on a Common Consolidated Corporate Tax Base (CCCTB) (7), a corporate tax system which treats the Union as a single market for the purpose of computing the corporate tax base of companies would facilitate cross-border activity for companies resident in the Union and promote the objective of making it a more competitive location for investment internationally especially for small and medium-sized enterprises. The proposal of 2011 for a CCCTB focussed on the objective of facilitating the expansion of commercial activity for businesses within the Union. In addition to that objective, it should also be taken into account that a CCCTB can be highly effective in improving the functioning of the internal market through countering tax avoidance schemes. In this light, the initiative for a CCCTB should be re-launched in order to address, on an equal footing, both the aspect of business facilitation and the initiative's function in countering tax avoidance. Once implemented in all Member States, a CCCTB would ensure that taxes are paid where profits are generated and where companies have permanent establishment. Such an approach would best serve the aim of eradicating distortions in the functioning of the internal market. Improving the internal market is a key factor for encouraging growth and job creation. The introduction of a CCCTB would improve economic growth and result in more jobs in the Union by reducing harmful tax competition between companies".
} 
this context is one of substantive similarity, i.e., similar rights and obligations, and not similarity of wording, this should be made clear in the text. In order to solve some interpretative issues, the Proposal for a Directive provides, in Article 3, some definitions relevant for its correct application, namely what are digital services, what is a digital interface, what is a user and what is the tax period.

According to the Proposal for a Directive under consideration, digital services are those provided over the Internet or an electronic network and the nature of which renders their supply essentially automated and requiring minimal intervention, and which would be impossible to provide in the absence of information technology. This definition includes the supply of digital products in general, services for creating or supporting the presence of businesses or individuals on an electronic network, services automatically generated by computers over the internet or an electronic network in response to specific data input by recipients, among others. ${ }^{29}$

Annex III lists the exceptions, i.e., the services that fall outside the scope of this Proposal for a Directive, including radio and television broadcasting services and the sale of physical goods facilitated by means of the internet or an electronic network. The rationale behind these exceptions is to ensure that taxation of digital services is not based on the place of consumption, but rather on where the value is created. And, although it is not duly densified in the proposal for a directive, the concept of minimal human intervention allows the exclusion, for example, of the services provided by lawyers or consultants via email, as these services normally require more than minimal buman intervention.

Another very important concept introduced by the Proposal for a Directive is that of significant digital presence (Article 4). This concept is intended to introduce a taxable nexus in a certain jurisdiction and should be regarded as a complement to the existing concept of permanent establishment. Thus, for corporate tax purposes, a (digital) permanent establishment is deemed to exist if there is a significant digital presence_through which the activity is wholly or partly carried on. And a significant digital presence is considered to exist, in a Member State, in a tax period, if the activity carried on consists wholly or partly of the supply of services through a digital interface, where one of the following conditions is met:

a) total revenue in a taxable period from the supply of digital services to users located in a particular Member State exceeds EUR 7000000.

b) the number of users of the digital service provided exceeds 100000 .

c) the number of business contracts for digital services concluded in a certain tax period by users located in that Member State exceeds 3000 .

The location of users, as opposed to, for example, the origin of the payment, is the key for determining the place of taxation.

For the purposes of using digital services, a user is deemed to be located in a Member State where they use $e^{30}$ their device - by reference to IP address or any

\footnotetext{
${ }^{29}$ Under this Proposal the scope of taxable services is considerably broader compared to the Proposal for a Directive 2018/0073.

${ }^{30}$ This concept of access to the website or a mobile application is not clear. Is it enough for the user to click on the website for this click to count as relevant use of the service? And where is the user considered to be located? At his or her home address? Should users travelling on business and accessing the digital interface in a Member State other than their residence also be counted? Or when in a flight making stopovers in several countries the user accesses the Internet in the various stopover countries will this count as relevant use of the service for the purposes of applying the criteria laid down in the proposal of a directive? I believe that all these questions will arise in practice, since the Proposal has not densified the concepts.
} 
other method of geolocation ${ }^{31}$ - to access the digital interface through which the service is provided.

In relation to the conclusion of contracts, instead of the location of users, the Commission chooses the criteria of the tax residence of the contracting company or, if the contractor resides in a third country, the existence of a permanent establishment in a certain Member State.

The criteria put forward by the European Union to establish a taxable link of a digital company in a certain Member State are benchmarks to determine the "digital footprint" of a company in a jurisdiction based on certain indicators of economic activity. In the words of the Commission in the preamble to the Proposal for a Directive 2018/0072, "the criteria should cater for different types of business models. Digital business models are very heterogeneous. Some may have a very large user base while others may have a smaller user base, but may still have significant user contributions if each individual user contributes a large value". Further adds that "As explained in the Impact Assessment it is essential that each threshold is set sufficiently high to safely exclude small cases where profits attributable to a digital presence would not even cover the tax compliance cost for a permanent establishment, thus to ensure proportionality of the measure while operating these three alternative thresholds".

The use of quantitative benchmarks in defining a nexus of significant digital presence, while aiming to provide clarity and certainty and to create a level playing field for all market participants, may be considered arbitrary. Indeed, fixed figures regarding the existence of a significant user base in a jurisdiction do not take into account the market differences between the various European Union Member States in terms of geography, size of the economy or number of inhabitants. The chances of a fixed number threshold being met in a small European Union Member State are limited compared to a larger one, even though non-residents potentially have a more extensive significant presence in the small State's market. In particular, as regards the threshold of the number of users, it is questionable whether this benchmark relates to value creation by users. Not all users contribute equally to a digital enterprise, and the various digital models allow for a different degree of engagement by the user. Furthermore, when measuring the number of users in a certain fiscal period, it is unclear how long it should be located in the home jurisdiction.

The wording of Article 4 also seems to ignore the user's place of residence, focusing only, for the purposes of determining where the revenue from the digital service supply is created, on where the user uses the services, or where business contracts are concluded. If a user has to travel, either for personal or professional reasons, that same user may be counted more than once for the purpose of counting thresholds. In addition, the same user may access the same website through multiple channels, which will make counting even more difficult.

In other words, although the Commission opens a way forward, there is room for improvement in terms of clarifying some concepts.

As regards the attribution of profits, the rules of this proposal of a directive are built on the current framework for permanent establishments.

The principle established is that the significant digital presence should be attributed to the profits it would have made if it were a separate entity engaged in the same digital transaction, taking into account the functions performed, assets used and risks

\footnotetext{
${ }^{31}$ From a personal data protection perspective, the Commission will need to coordinate this provision with the Personal Data Protection Regime, in particular with that provided for in Regulation (EU) 2016/679 of the European Parliament and of the Council of 27 April 2016.
} 
assumed through the digital interface. ${ }^{32}$ Thus, the functional analysis of a significant digital presence should consider the activities performed through a digital interface related to data and users as economically significant functions for the attribution of economic ownership of assets and risks to the digital permanent establishment. The total profits earned shall be calculated by attributing profits proportionally to the number of times devices are used to access the digital interface through which the covered services are provided.

This provision aims to ensure that, in the context of digital activities, the attribution of profit to significant digital presence reflects the value created through the services provided. Such a situation occurs where a significant digital presence operates through a digital interface without any physical presence or without any significant human function. The attribution of profit should take into account the development, enhancement, maintenance, protection and exploitation of intangible assets in the performance of the economically significant activities by the digital presence even if these are not linked to people functions in the same Member State.

The Proposal for a Directive, in the detailed explanation of the provisions, provides an example of this Article 5: "in attracting new users to a social network, the set of intangible assets that would be attributable to the business of the social network plays a key part in guaranteeing the positive network externalities, i.e., that the users are able to connect to a large number of other users. (...) This set of intangibles would be further enhanced by the processing of user-level data to enable the social network to sell advertising space at a premium since the advertising space is customised to the interests of the users. ${ }^{133}$

It follows that each of the economically relevant activities contributes to the creation of value of the digital business model and is an integral part of it. The profit split method, in the EU perspective set out in this proposal for a directive, would appear to be the most appropriate for allocating profits to significant digital presence. ${ }^{34}$

In order to examine questions concerning the application of the Proposal for a Directive and to evaluate its implementation, the Commission agreed to set up an advisory committee called DigiTax, composed of representatives of the Member States and of the Commission and chaired by a Commission representative.

This Proposal for a Directive is an acknowledgement of the need for a paradigm shift in the international tax system.

However, what the Commission has done was establish the bases on which concepts such as significant digital presence or digital services would be constructed, leaving the definition of their more specific contours to the competent international bodies. ${ }^{35}$

The traditional rules of International Tax Law require the determination of some criteria connecting the taxing power. The concept of permanent establishment is the main territorial connection criterion that allows the exercise of the taxing power, ensuring a fair balance between the exclusive taxation of the State of residence and the State of source, where the income was effectively created.

\footnotetext{
${ }^{32}$ See detailed explanation of the specific provisions of Proposal for a Directive 2018/0072, 9.

${ }^{33}$ Considering the role of users and their data in a functional analysis of imputing risks and assets (and ultimately profits) to the digital permanent establishment is consistent with the significant role that users play as a value driver of digital business models.

${ }^{34}$ It is worth noting that the profit split method is, like all other transfer pricing methods, a "transactional" method.

${ }^{35}$ Certainly, convinced that a solution on this issue will have to be taken at global and not regional level.
} 
The traditional concept of permanent establishment must be rethought to ensure that, through the location of its users, a company - whose activity relies on the use of a digital platform - is recognised as having a significant digital presence and thus provide the Member State where that digital footprint occurs with taxing powers that allow it to access its share of the taxes relating to the business/digital activities carried out on its territory.

The Proposal for a Directive has also not foreseen how companies that provide services or sell digital and non-digital goods may be subject to double taxation, at source and at residence, which we believe should be distinguished. Moreover, the three criteria regarding the amount of revenue earned, number of users and number of business contracts concluded - which are applied cumulatively - do not reflect the concept of permanence over time, which is typical of the traditional permanent establishment concept. It might be appropriate to add a time criterion, to exclude certain one-off arrangements from tax liability, and to revisit the figures now provided on an annual basis to ensure that they are in line with reality.

Despite these considerations, it is easy to see the Commission's difficulty in creating clear and concise rules that, at the same time, cover the whole range of taxable situations in the digital economy. Nonetheless, it seems that the proposal points out the most relevant digital services, focusing on the creation of value by users and on the operations carried out through a digital interface related with data from those same users, which are, perhaps, the most relevant activities in the scope of goods and services provided by this type of businesses.

\subsection{Common System of a Digital Services Tax - Proposal for a Directive 2018/0073}

In parallel, and pending the adoption of a comprehensive solution, and to avoid the adoption of divergent unilateral measures by Member States that may weaken the Single Market, the European Commission has also presented, as an interim solution, the Proposal for a Council Directive on the common system of a digital services tax on revenues resulting from the provision of certain digital services — 2018/0073 (CNS).

The Proposal for a Directive no. 2018/0073 introduces an indirect tax (the DST), at a rate of $3 \%$, levied on gross revenues arising from the provision of certain digital services.

It differs from the Proposal for a Directive 2018/0072 (CNS) since its scope is much narrower. The Proposal for a Directive 2018/0073 creates a tax, levied on revenues derived from the provision of certain digital services, characterised by the creation of value by the user. Digital services should be those that depend to a large extent on the creation of value by the user, where the difference between the place where the profits are taxed and the place where the users are established is generally greater. The value subject to taxation is the revenue ${ }^{36}$ from processing the user input, not the user participation itself.

\footnotetext{
${ }^{36}$ On this subject Hans Van den Hurk, "Tax and Digital Economy - Will pillar one be the solution?”, 134: "should a tax based on revenues not be considered a VAT? I tend to think so. (...) In my humble opinion I like to refer to the expression if it looks like a duck, it sounds like a duck and it walks like a duck, it might as well be a duck".
} 
As regards the objective scope, the proposal of a directive specifies the digital services whose revenues are subject to the tax:

a) The placing on a digital interface ${ }^{37}$ of advertising targeted at users ${ }^{38}$ of that interface;

b) The making available of multi-sided digital interfaces to users to find other users and to interact with them, and which may also facilitate the provision of underlying supplies of goods or services directly between users (also referred to as "intermediation services"); $3^{39}$

c) And the transmission of data collected from users and generated from the activities of those users on digital interfaces.

Is important to clarify that, according to Article 3(7) of the Proposal for a Directive, any revenues derived from the provision of services to another group company are excluded from the scope of the tax. In other words, the tax is levied only on revenues derived from the provision of digital services to third parties, whether companies or individuals.

Article 3 of this Proposal for a Directive extensively delimits the object of the tax, and, in my opinion, especially if we consider the explanatory notes to this article, the line separating taxable and non-taxable services remains somewhat blurred. However, the main idea is that the revenue derived from the provision of certain digital services is the revenue derived from the value created by users and not from the digital service itself.

The location of the user is again fundamental since it is where value is created.

According to Article 5 of the Proposal for a Directive, and in line with the concept of value creation by users, which underpins the scope of the tax, the tax would be levied by the Member State where the users are located, regardless of whether the user has contributed in cash to the generation of the revenue.

Similarly, to Proposal of a Directive 2018/0072, the location of users is done based on the IP (Internet Protocol) address of the device used, or by any other means of geolocation that proves to be more accurate. ${ }^{40}$

When users, involved in a taxable digital service, are located in different Member States or in jurisdictions outside the European Union, the Proposal for a Directive determines that taxable revenues obtained through the provision of such services should be distributed proportionately among each Member State.

To manage the administrative aspects related to the payment of this tax, the Proposal for a Directive provides for the creation of a One-Stop-Shop. This is based on the idea that the taxable person with DST liability should have a single contact point (the Member State of identification) where he or she will have to comply with all obligations relating to the tax - namely identification, submission of the return and payment of the DST - and the Member State of identification is responsible

\footnotetext{
${ }^{37}$ Digital interface is defined in Article 2(3) of the Proposal for a Directive as "any software, including a website or a part thereof and applications, including mobile applications, accessible by users".

${ }^{38}$ The concept of user can be found in Article 2(4) and means any individual or business.

${ }^{39}$ In this regard, the Proposal for a Directive explanatory note clarifies that the difference between a supplier selling goods or services online for his own account or providing intermediation services would be determined by taking into account the legal and economic substance of a transaction.

${ }^{40}$ According to Article 5(6) only data indicating the Member State where users are located should be shared, without allowing those users to be identified. This provision was introduced perhaps to mitigate potential conflicts that could arise regarding the protection of personal data, in particular the Regulation (EU) 2016/679 of the European Parliament and of the Council of 27 April 2016.
} 
for sharing this information with other Member States where the tax is due and for transferring the proportion collected on behalf of those States.

The fact that a taxable person is resident for the purpose of paying corporate income tax in a Member State has no impact on the determination of the Member State of identification for the purpose of paying DST - given the different nature of the tax. Thus, the Member State of identification should be the State where the DST is due, except in cases where the tax is due in more than one State, in which case the taxpayer may choose the respective Member State of identification. Despite these provisions, the DST is due directly to each Member State, which means that the Member State concerned has the right to enforce its payment against the taxable person liable for the tax and to carry out tax audits and control measures.

The subjective scope of the Proposal for a Directive is delimited by Article 4, which defines who is subject to the tax.

As provided in Article 2 of this Proposal for a Directive, any person or entity, regardless of their legal form or State of residence, may be subject to DST, provided that they meet (cumulatively) two discriminative criteria.

The first criterion relates to the size of the entity: entities which, in a tax period, have total global revenues greater than EUR 750000000 are subject to the tax.

The second criterion relates to the "digital footprint" of the entity within the European Union, in that entities are subject to the tax if, in a tax period, their total taxable income within the European Union exceeds EUR 50000 000. ${ }^{41}$

The first threshold (total annual global revenues) limits the application of this tax to companies of a certain size, which are the ones establishing strong market positions that allows them to benefit from the network effects and the exploitation of big data. Moreover, the opportunities for aggressive tax planning lie with the largest companies. This threshold is intended to bring legal certainty and make it easier and less burdensome for businesses and tax administrations to determine an entity's DST obligation, excluding small businesses and start-ups from the obligation of yet another tax that could even become disproportionate. The second threshold (total annual revenues in the Union) is intended to limit the application of the tax to cases where there is already a strong "digital footprint" at EU level.

An obvious criticism of the application of these thresholds is that they may discourage growth beyond this level of revenue. Furthermore, subjecting a company to a $3 \%$ levy on gross revenues can be significant, even at the revenue scale of 750 million euros, since the profit margins may be very small.

The second criterion is applied to exclude from the DST scope those big companies that, in spite of their size, have an "irrelevant" number of digital services in the European Union. But we will say that, while it is relatively simple to assess the revenue threshold by looking at the company's financial statements, assessing such a digital footprint is anything but straightforward. When we talk about digital services, regarding a company that operates globally is difficult to know what taxable revenues are earned within the EU just by looking at the company's financial statements.

However, the fact is that this interim solution provided for by the Proposal for a Directive 2018/0073 offers a balanced response to, on the one hand, the Member States' taxation requirements and, on the other hand, the healthy economic growth,

\footnotetext{
${ }^{41}$ It seems to me that this requirement is quite interesting since it applies to revenue obtained in the European Union and not in a particular Member State.
} 
insofar as it presents a stable tax framework for companies active in the European Union.

So much so that this type of tax has already been implemented in countries like France (3\%), Austria (5\%), Spain (3\%), Hungary (7.5\%), Italy (3\%) and Poland $(1.5 \%)$. And while, for example, Austria and Hungary only tax revenues from online advertising, in France the taxable base is much broader, including revenues from the provision of digital interfaces or targeted advertising. ${ }^{42}$

In Portugal, the proposal to create a tax on certain digital services presented by the party Bloco de Esquerda was not accepted. ${ }^{43}$

The abovementioned proposals should have been transposed by the Member States by 31 December 2019, and the transpositions should apply from 1 January 2020. To this date, that transposition process has not taken place, most likely due to a lack of unanimity on the matter.

\section{Conclusion}

The legislative framework presented by the Commission will have to be reviewed once the members of the G20 translate the Global Agreement into a multilateral convention. ${ }^{44}$

Although different in scope, both proposals for directives demonstrate a strong concern from the Commission to close this legislative loophole that encourages tax planning and avoidance by technological companies.

It should be noted that tax systems need to take due account of new business models, and there is a strong belief that any change to the rules for distributing taxing rights between countries should be coordinated on a global scale, otherwise this will result in double taxation and, consequently, a reduction in investment and jobs. However, if an international solution cannot be reached, the European Union should consider (as it has through these two Proposals for Directives), to move forward alone. ${ }^{45}$

What the European Economic and Social Committee noted, in its own-initiative opinion on "Taxation in the digitalised economy" of 17 July 2019, and which seems interesting to reproduce, is that the "discussion regarding the taxation of so-called digital companies does not primarily relate to base erosion and profit shifting behaviour of companies but to the allocation of taxation rights among countries". ${ }^{46}$

Legislation, regarding taxation, is closely linked to national sovereignty given the role this matter plays in national revenue, state budgets and political choices.

\footnotetext{
${ }^{42}$ Elke Asen, "What European OECD countries are doing about Digital Services Taxes", Tax Foundation, March 25, 2021, accessed August 20, 2021, https://taxfoundation.org/digital-taxeurope-2020/.

${ }^{43}$ Projecto de Lei no. 1123/XIII/4. ${ }^{\text {a }}$ (BE), accessed August 20, 2021, https://bit.ly/3jStTCK

${ }^{44}$ Once there is a consensus-based global agreement on both Pillars, the Commission will move swiftly to propose measures for their implementation in the EU, in line with the EU's tax agenda and the needs of the Single Market. European Commission, "Global Agreement on Corporate Taxation: frequently asked questions”, accessed August 20, 2021, https:/ / ec.europa.eu/commission/ presscorner/detail/pt/qanda_21_3564.

${ }^{45}$ Opinion of the European Economic and Social Committee on "Taxation in the digitalised economy" (2019/C 353/04), accessed August 20, 2021, https:// eur-lex.europa.eu/legal-content/PT/TXT/PD $\mathrm{F} /$ ?uri=CELEX:52018IE2781\&from $=\mathrm{EN}$.

46 Opinion of the European Economic and Social Committee on "Taxation in the digitalised economy", accessed August 20, 2021, https:/ / eur-lex.europa.eu/legal-content/EN/TXT/PDF/?uri $=$ CELEX:52018IE2781\&from $=\mathrm{EN}, 4.6$.
} 
Taxation is the last EU policy area where decision-making is based exclusively on unanimity. ${ }^{47}$

However, the unanimity rule ${ }^{48}$ prevents taxation from fulfilling the goal of preserving the Single Market and supporting inclusive growth in different countries. Taxation is essential for building a strong and dynamic Single Market, for attracting businesses and investors, generating jobs, and influencing business decisions of expanding. Essentially, it is a key element in ensuring social justice.

But to achieve this, it is essential that tax systems are uniform within the European Union.

Nonetheless, it seems to me that in this area, unanimity in tax matters has proved counterproductive. It is legitimate to ask, if one Member State can veto a tax initiative sought by the other 26 Member States, to what extent the can unanimity rule defend the sovereignty of these 26 Member States.

The alternative would be to change the voting requirements to qualified majority regarding European Union tax policy. And the fact is that the Treaties contain provisions allowing recourse to procedures other than unanimity, without being necessary to amend the Treaty itself.

Take, for example, the enhanced cooperation procedure, ${ }^{49}$ which allows a group of at least nine Member States to propose an initiative jointly when unanimous agreement cannot be reached in the Council; or Article 116 of the TFEU, which allows qualified majority voting with ordinary legislative procedure to eliminate distortions of competition due to different national tax rules if this cannot be resolved in agreement with the Member States. ${ }^{50}$ And perhaps the most practical way of moving from unanimous voting to qualified majority voting without amending the Treaties would be to use the so-called "bridging clauses" in the Treaties. ${ }^{51}$

Moving to qualified majority voting would not affect Member States' existing powers in the area of taxation. It would only change the decision-making procedure applicable in the future, as agreed unanimously by Member States exercising their sovereignty. ${ }^{52}$

It is clear that the digital economy poses more profound questions other than how it is taxed, as it implies the need for more effective legislation on the European Union tax policy.

\footnotetext{
${ }^{47}$ The Single European Act, of 1986, which entered into force on 1 July 1987, in relation to voting matters replaced unanimity by qualified majority as the general rule for harmonising single market rules. This was followed by further steps extending qualified majority voting to a wide range of policies, including judicial cooperation in civil matters, harmonisation in the field of criminal law and police cooperation. Moreover, taxation is still one of the few areas where decisions are taken by a special legislative procedure, taxation initiatives are taken by the Council on a proposal from the Commission, and the European Parliament has a purely consultative role.

${ }^{48}$ According to Articles 113 and 115 of the Treaty on the Functioning of the European Union (TFEU), the rule is that the Council must act unanimously on tax proposals under the special legislative procedure. Also, Articles 192(2), first subparagraph, and 194(3) TFEU establish that provisions of a primarily fiscal nature regarding environment and energy should be adopted unanimously by the Council in accordance with the special legislative procedure.

${ }^{49}$ Article 20 of the Treaty on European Union (TEU) and Articles 326 to 334 of the TFEU.

${ }^{50}$ This provision, which has not been used to date, is subject to strict conditions and does not resolve all the shortcomings that currently arise from the unanimity rule in tax matters.

${ }^{51}$ In accordance with Article 48(7) TEU the Council may adopt a decision authorising the Council to act by qualified majority in that area or in that case. Any initiative taken by the European Council shall be sent to national Parliaments to oppose it within a period of six months.

${ }^{52} \operatorname{COM}(2019) 8$ final, 12.
} 
No progress is being made on tax matters in the European Union, or the one made is slow, because there is no unanimity or consensus between the Member States on these matters. But unanimity is no longer a practical and effective way of making decisions. National interests and those of the European community are intertwined, and perhaps moving to qualified majority voting on tax matters could help end this deadlock and bring some legal certainty and stability to businesses across the European Union.

International bodies must continue the debate on this issue to achieve a system that is fair, proportional and, most importantly, adapted to the digital reality. However, more than debate, action is needed. The OECD/G20 Inclusive Framework will take a final decision on the remaining issues and will agree on an implementation plan by October 2021, and once the terms of the agreement are settled, it will be important that the European Union ensures its implementation in a consistent way across the Member States. 